\title{
Melatoninaren eraginkortasuna loezina arintzeko: saio klinikoen berrikusketa sistematikoa
}

\author{
(Efficacy of melatonin in the treatment of insomnia: \\ a systematic review of clinical trials)
}

\author{
Ane Barreras, Irati Rodilla, Aitziber Mendiguren* \\ Farmakologia Saila, Medikuntza eta Erizaintza Fakultatea (UPV/EHU)
}

\begin{abstract}
LABURPENA: Loezinak, loak hartzeko edo mantentzeko zailtasunari, behar baino lehenago esnatzeari zein indarberritzailea ez den loa edukitzeari egiten dio erreferentzia. Loezinak erritmo zirkadianoaren lo-esnatzearen alterazioak (adibidez, loaldi atzeratuaren sindromea edo lan txandekin lotutako loezina) eta ez-REM loaren esnatze asaldurak (somnanbulismoa, gaueko ikarak edo amesgaiztoak, besteak beste) barnebiltzen ditu. Loezinaren tratamendurako gehien erabiltzen diren farmakoek (bentzodiazepinek eta Z-hipnotikoek) eragin kaltegarri ugari dituzte eta epe luzera erabiltzeko ez dira gomendagarriak. Horregatik, loezina tratatzeko, ustez segurtasun hobea eta eraginkortasun bera duten alternatibak merkaturatu dira, adibidez, melatonina. Azken urteotan, melatoninaren erabilera asko handitu da eta adin guztietako pazienteengan loezin mota ugari arintzeko erabili izan da, baina ez dago argi erabilera hori ebidentzian oinarrituta dagoen. Horregatik, lan honen helburua gaixotasunekin erlaziorik ez zuen adin guztietako pazienteengan melatoninak loezina arintzeko duen eraginkortasuna aztertzea izan zen. Horretarako, plazeboarekin kontrolatutako entsegu klinikoen berrikusketa sistematikoa egin zen. Aztertutako saioen arabera, melatonina ( $2 \mathrm{mg}$-ko dosian, 3 astetan zehar) lehen mailako loezinerako eraginkorra da bai lolatentzia laburtzeko bai lo-kalitatea eta pazienteen ongizatea eta bizi kalitatea hobetzeko. Loezin mota zehatzetarako, aldiz, dauden ebidentziak urriak dira. Adinari dagokionez, melatonina 55 urtetik gorako pazienteengan loezina arintzeko eraginkorra dela frogatu da. 55 urtetik beherako pazienteengan, ostera, eraginkortasuna frogatu duen entsegu bakarra bildu da. Ondorio orokor gisa esan daiteke melatonina eraginkorra dela 55 urtetik gorako pazienteengan lehen mailako loezina arintzeko, $2 \mathrm{mg}$-ko dosian eta 3 astetan zehar administratzen denean. Beste adineko pazienteengan, dosi baxuagotan edota loezin zehatz batzuetan egiten den erabilera, aldiz, ez dago ebidentzian oinarrituta.
\end{abstract}

HITZ GAKOAK: loezina, melatonina, entsegu klinikoa, berrikusketa sistematikoa.

\begin{abstract}
Insomnia designates the difficulty in falling or staying asleep, waking up earlier than needed or having a non-refreshing sleep. It includes both circadian rhythm sleep-wake disorders (e.g. delayed sleep phase syndrome or shift work sleep disorder) and non-REM sleep arousal disorders (somnambulism, sleep terrors or nightmares, among others). The most used drugs for insomnia (benzodiazepines and Z-hypnotics) produce many adverse effects and are not recommended for long-term use. Therefore, alternatives presumably showing better safety and same effectiveness have been commercialized, e.g. melatonin. Recently, the use of melatonin to alleviate any type of insomnia in patients of all ages has greatly increased, but it is unclear whether its use is evidence-based. Thus, the aim of this work was to evaluate the efficacy of melatonin to alleviate primary insomnia in patients of all ages by conducting a systematic review of placebo-controlled clinical trials. Melatonin ( $2 \mathrm{mg}, 3$ weeks) is effective in primary insomnia to shorten sleep latency and to improve sleep quality, wellness and quality of life. Nevertheless, few trials address specific types of insomnia. Studies show that melatonin is effective to alleviate insomnia in patients older than 55 years. However, only one trial has been conducted in patients under 55 years old. We conclude that melatonin ( $2 \mathrm{mg}, 3$ weeks) is effective in patients older than 55 years to alleviate primary insomnia, but its use in younger patients, at smaller doses or in other types of insomnia is not evidence-based.
\end{abstract}

KEYWORDS: insomnia, melatonin, clinical trial, systematic review.

* Harremanetan jartzeko / Corresponding author: Aitziber Mendiguren. Farmakologia Saila, Medikuntza eta Erizaintza Fakultatea, UPV/EHU. - aitziber.mendiguren@ehu.eus - https://orcid.org/0000-0002-1990-0493

Nola aipatu / How to cite: Barreras, Ane; Rodilla, Irati; Mendiguren, Aitziber (2022). «Melatoninaren eraginkortasuna loezina arintzeko: saio klinikoen berrikusketa sistematikoa». Ekaia, 42, 2022, 25-47. (https://doi.org/10.1387/ekaia.22913).

Jasotze-data: 2021, ekainak 16; Onartze-data: 2021, irailak 23.

ISSN 0214-9001 - elSSN 2444-3255 / (c) 2022 UPV/EHU

(i) (-) $\odot$ Lan hau Creative Commons Aitortu-EzKomertziala-LanEratorririkGabe 4.0 Nazioartekoa lizentzia baten mende dago 


\section{SARRERA}

Amerikako Psikiatria Elkartearen Buruko Nahasteen Diagnostiko eta Estatistika Eskuliburuaren (DSM-5) arabera, loezinak loak hartzeko edo mantentzeko zailtasunari, espero baino lehenago esnatzeari edo indarberritzailea ez den loari egiten dio erreferentzia. Sintoma horiek gutxienez hiru hilabetean zehar astero hiru gautan agertu behar dira. Gainera, lo-alterazioak edo ondoriozko biharamuneko nekeak hondatze kliniko esanguratsua eragin behar du inguru sozialean, lan inguruan edo eguneroko funtzionamenduan. DSM-5en arabera loezina bi taldetan sailkatzen da: erritmo zirkadianoen lo-esnatzeen asaldurak (loaldi atzeratuaren sindromea, loaldi aurreratuaren sindromea, lan txandekin lotutako loezina edo loezin ezzehaztua) eta ez-REM loaren esnatze asaldurak (somnanbulismoa, gaueko ikarak, hanka geldiezinen sindromea edo amesgaiztoak) [1]. Biztanleen $\%$ 10ek loezinaren irizpideak betetzen ditu eta, askotan, hilabete zein urteetan zehar luzatu daitekeen gaixotasuna da [2].

Loezinaren tratamenduari dagokionez, bi aukera bereiz daitezke: neurri ez-farmakologikoak (neurri higieniko dietetikoak eta terapia psikologikoak) $[3,4]$ eta bestetik, farmakoterapia. Farmakorik erabilienak bentzodiazepinak eta Z-hipnotikoak dira. Horien eragina, garuneko GABA hartzaileen bidez gertatzen da eta horrela, loaren egitura aldatzen dute [5]. Hala ere, farmako horiek epe luzera ez dira gomendagarriak eragin desiragaitz ugari dituztelako, hala nola aurreranzko amnesia, menpekotasuna eta tolerantzia [6]. Loezinerako erabili daitezkeen beste farmako multzoek (antihistaminikoak, antidepresiboak edo antipsikotikoak) ere eragin kaltegarriak dituzte eta pazienteen artean aldakortasun handia dago eraginkortasunari dagokionez [7]. Azken urteotan farmako berriak merkaturatu dira; horien artean, melatonina.

Melatonina guruin pinealak jariatutako hormona da eta haren sintesia iluntasunak indartu eta argiak inhibitzen du. Hipofisi eta nukleo suprakiasmatikoko MT1 eta erretinako MT2 hartzaileak lotzen dituenez, neuronen inhibizioa, funtzio neurokonduktualen gutxitzea eta logura eragiten ditu $[8,9]$. Hortaz, melatoninak lo-esnatze zikloa eta erritmo zirkadianoa arautzen ditu [10], eta horregatik loezina tratatzeko farmako gisa erabiltzen hasi da.

Loezina arintzeko farmakoek duten eragina aztertzeko egiten diren ikerketetan neurri objektiboak (polisomniografia adibidez) zein galdetegi, eskala edo egunerokoak erabiltzen dira. Loaren kalitatea neurtzeko, ikerketa askotan Leeds Sleep Evaluation Questionnaire (LSEQ) eskala erabili izan da. LSEQk loak hartzeko erraztasuna, lo-kalitatea, esnatzean gertatzen den ajea eta biharamuneko alerta maila eta jokabidea neurtzen ditu [11]. Bestetik, loaren asaldura orokorra neurtzeko Pittsburgh Sleep Quality Index (PSQI) eskala erabiltzen da. PSQIk 7 parametro aztertzen ditu; lo-kali- 
tate subjektiboa, lo-latentzia, lo-denbora osoa, lo-efizientzia, lo-asaldurak, loa hobetzeko medikazioaren erabilera eta eguneko disfuntzioa [12]. Multiple Sleep Latency Test (MSLT) eskalak lo-latentzia (loak hartzeko erraztasuna eta modua) neurtzea du helburu [13]. Ostera, Leeds Psychomotor Test (LPT) eskala alderdi objektiboak (nerbio sistema zentralaren eszitazio maila eta integrazio potentziala) eta errendimendu psikomotorra neurtzeko baliogarria da [14]. Global Vigor and Affect (GVA) eskalak, aldiz, kemena eta arazeria aztertzen ditu. Eskala hori jet lag eta lo-gabetzerako erabilgarria da [15]. Lo-egunerokoak, lo-kalitatea, lo-latentzia eta egunean zeharreko kalitatea neurtzeko baliogarriak dira. Azkenik, eskala bisual analogoak (VAS) alderdi subjektiboak neurtzeko erabiltzen dira, adibidez, lo-kalitatea [16].

Ongizatea eta bizi-kalitatea neurtzeko, World Health Organisation-5 (WHO-5) eskala erabil daiteke, hau da, Munduko Osasun Erakundeak proposatutako galdetegia. Umore positiboa, lasaitasuna, erlaxazioa eta energia maila, loaren kalitatea eta eguneko interes orokorrak neurtzen ditu [17]. Clinical Global Scale (CGI) eskalaren bidez, aldiz, pazienteak orokorrean pairatutako hobekuntza klinikoa neurtzen da [17]. Azkenik, Tyrer galdetegiak tratamendua kentzearen efektuak aztertzen ditu [18].

\section{HIPOTESIA ETA HELBURUA}

Loezinaren tratamendurako erabilitako farmako ohikoenek eragin desiragaitz ugari dituzte eta epe laburrean erabili behar dira [6]. Azken urteotan loezina tratatzeko beste aukera farmakologikoak erabiltzen hasi dira, melatonina kasu. Melatonina 2011. urtean onartu zen farmako gisa eta 55 urtetik gorako pertsonengan lehen mailako loezina tratatzeko merkaturatuta dago, epe laburrean eta monoterapian [19]. Hala ere, azken urteotan melatonina adin guztietako pazienteengan eta loezin arazo desberdinak tratatzeko erabilia izan da. Gaur egun, melatonina dosi desberdinak dituzten produktu ugari daude merkaturatuta eta horien salmenta biziki handitu da, nahiz eta argi ez dagoen erabilera zabal hori ebidentzian oinarrituta dagoen. Horregatik, gure helburua adin guztietako pazienteengan gaixotasunekin erlaziorik ez zuen loezina arintzeko melatoninak duen eraginkortasuna aztertzea izan da. Horretarako, plazeboarekin kontrolatutako zorizko esleipenezko saio klinikoen berrikusketa sistematikoa egin da.

\section{MATERIALA ETA METODOAK}

\subsection{Bilaketa-estrategia}

Artikuluen bilaketa 2017ko abenduan egin zen. Entsegu klinikoen bilaketa egiteko bost datu-base erabili ziren: Pubmed, Askmedline, Tripdata- 
base, Clinical Trials eta Cochrane. Bilaketa sakona egiteko asmoz, finkatutako helburuen hitz-gako posibleen zerrenda prestatu zen PICO metodoan oinarrituta, eta honako lau atal hauek bereizi ziren:

- P (Population, Populazioa): aztertu nahi ditugun pazienteen ezaugarriak, hau da, gaixotasunekin erlaziorik ez duen loezina duten adin guztietako pazienteak.

- I (Intervention, Esku-hartzea): aztertuko dugun tratamendua, hau da, melatonina.

- C (Comparison, Konparaketa): beste tratamendu batekin konparaketa egitea, hau da, plazeboarekin konparatzea.

- O (Outcome, Emaitzak): aztertu nahi ditugun eraginetarako neurketa mota, hau da, lo-denbora, lo-kalitatea edo erlazionatutako aldagaiak.

Azaldutako lau atal horietako bakoitzerako termino askeak (T) eta Pubmed-eko MeSH terminoak (MT) erabili ziren. Termino hauek «OR» lokailuarekin lotu genituen PICOren atal bakoitzerako eta gero «AND» lokailuaren bidez erlazionatu genituen PICOren lau atalak (ikus 1. irudia).

Pubmed-en aipamen gehien zituzten terminoak aukeratu genituen beste datu-baseetan bilaketa egiteko. Horrela, Clinical Trials eta Cochrane-n kasuan bilaketa zuzenean egin zen «sleep disorder», «melatonin» eta «sleep time» terminoak «AND» lokailuarekin konbinatuz.

Azkenik, Askmedline eta Tripdatabase-n kasuan, zuzenean datu-basean egin zen bilaketa PICO erabiliz. Horretarako «sleep disorder» (populazioa), «melatonin» (esku-hartzea), «placebo» (konparaketa) eta «sleep time» (emaitzak lortzeko neurketa motak) erabili ziren (ikus 2. irudia).

\subsection{Artikuluak aukeratzeko eta baztertzeko irizpideak}

Melatoninak loezina arintzeko eraginkortasuna zuen aztertzeko, plazeboarekin kontrolatutako zorizko esleipenezko entsegu klinikoak aukeratu genituen. Ez genuen saioetan erabilitako neurketa metodorik, eskalarik zein prozedurarik zehaztu. Era berean, tratamenduaren iraupenean, pazienteen ezaugarrietan, artikuluen argitaratze urtean eta loezin motetan ez genuen mugarik jarri. Baztertu genituen animaliengan egindako ikerketak, ingelesez ez zeudenak, melatonina ez zen beste tratamendu bat aztertzen zutenak, loezinaren gaineko eragina aztertzen ez zutenak, melatoninaren beste eraginak aztertzen zituztenak, loezina ez zuten pazienteak aztertzen zituztenak, loezinaz gain beste gaixotasun bat pairatzen zuten pazienteak sartzen zituztenak, melatoninaz gain beste tratamendu bat erabiltzen zutenak, zorizko esleipenezko entsegu klinikoak ez zirenak eta melatonina plazeboarekin alderatzen ez zituztenak. 


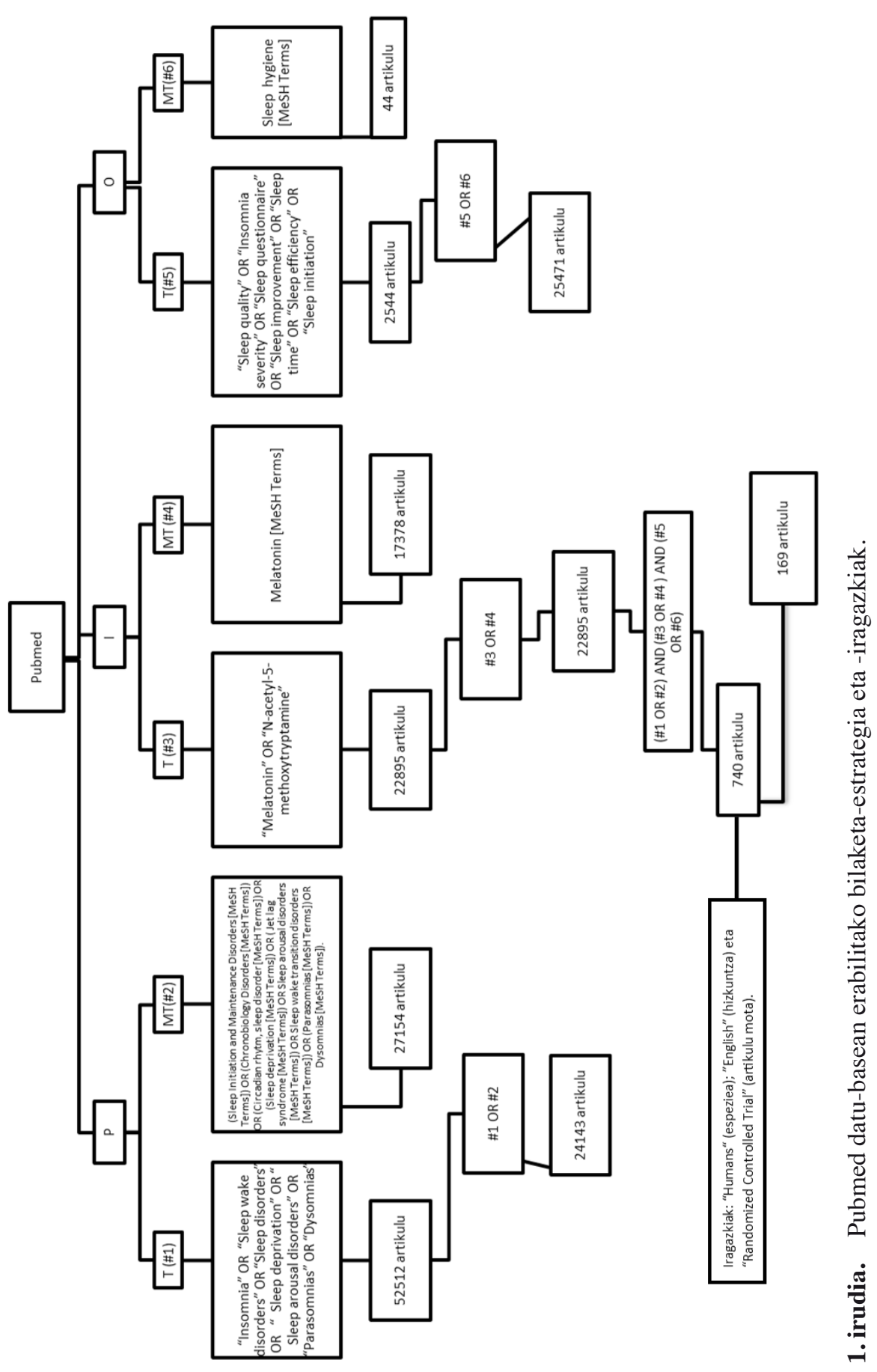



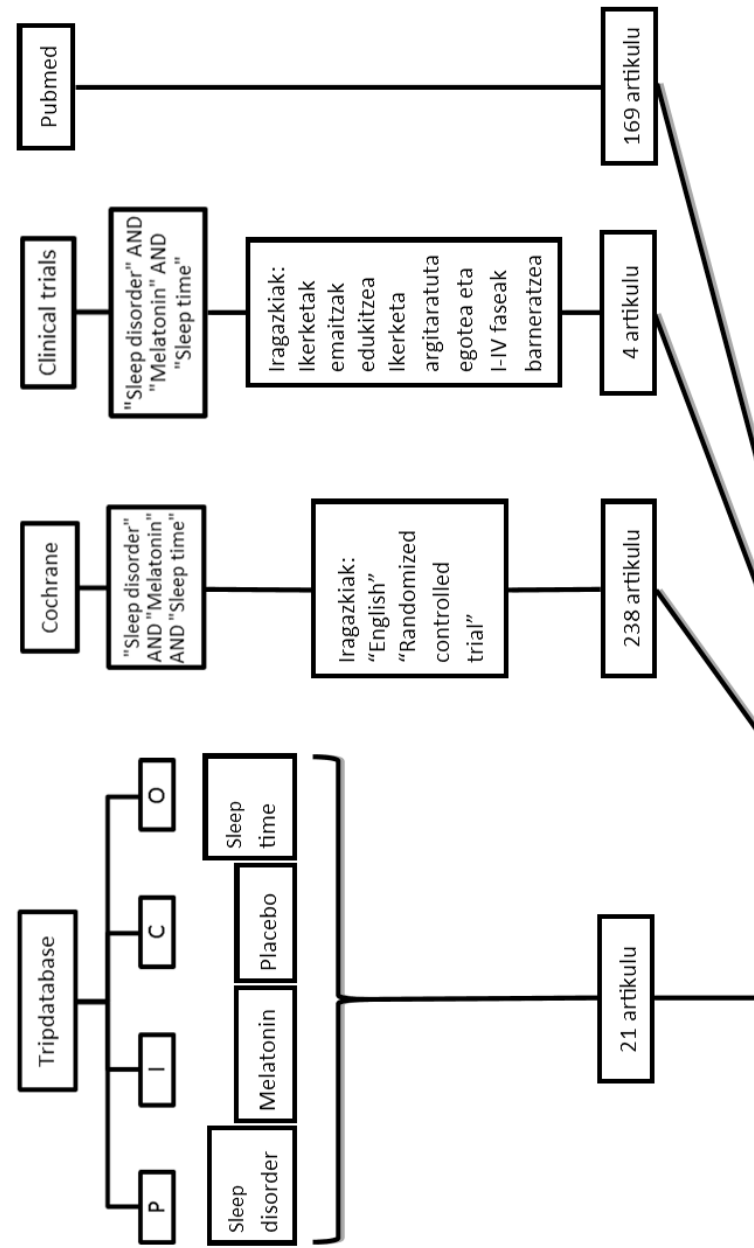

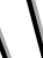




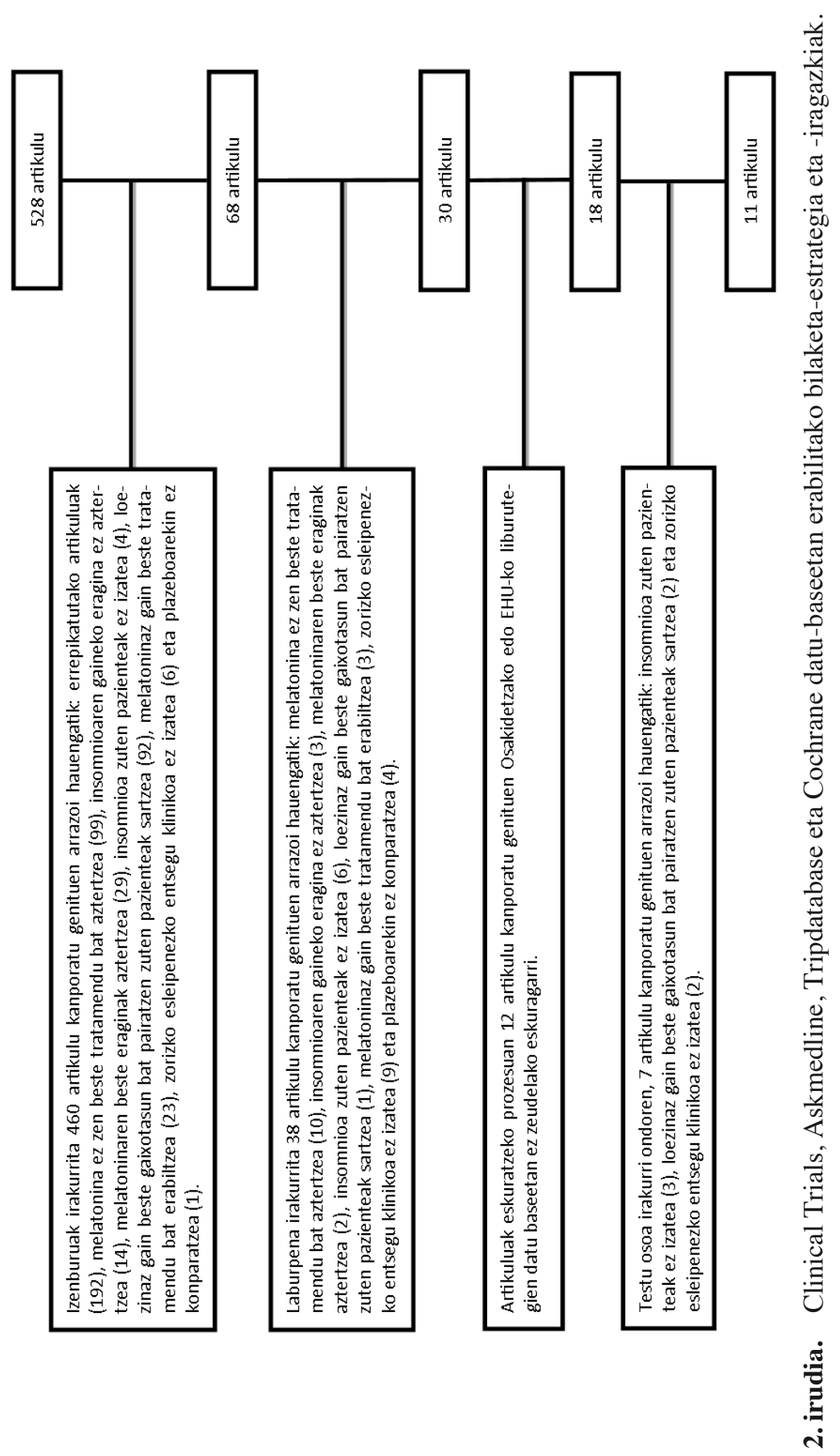


Pubmed eta Cochrane-en kasuan, artikuluak bilatzeko orduan iragazki hauek aplikatu ziren: «Humans» (gizakiengan egindako ikerketak biltzeko), «English» (ingelesez zeuden artikuluak aukeratzeko) eta «Randomized Controlled Trial» (zorizko esleipenezko entsegu klinikoak eskuratzeko). Askmedline-n kasuan, iragazki moduan «Randomized Controlled Trial» bakarrik aplikatu zen. Azkenik, Clinical Trials-en kasuan iragazkiak honako hauek izan ziren: ikerketek emaitzak edukitzea, ikerketak argitaratuta egotea eta I-IV faseak barneratzea (ikus 1. irudia eta 2. irudia).

\subsection{Artikuluen kalitatearen balorazioa}

Entsegu klinikoen metodologiaren kalitatea neurtzeko munduan gehien erabiltzen den JADAD eskala edo Oxford eskala erabili zen [20]. Eskala honek alborapenekin erlazionatutako alderdi ezberdinak hartzen ditu kontuan eta galdetegi arina, erraza eta balioztatua da. Funtsean, hurrengo bost galdera hauei erantzutean datza:

1. Zorizko esleipenezko ikerketa da?

2. Aleatorizazio-metodoa deskribatzen da eta berau egokia da?

3. Itsu bikoitzeko ikerketa da?

4. Itsutze metodoak erabiltzen dira eta horiek egokiak dira?

5. Ikerketan zehar gertatutako galerak eta atzera egiteak deskribatzen dira?

Galdera hauen erantzunen arabera, JADAD eskalak entsegu klinikoak $0-5$ puntuazioen artean sailkatzen ditu: puntuazioa $\geq 3$ bada saioak kalitate altua duela ondorioztatzen da eta $<3$ bada, aldiz, kalitate txikia.

\section{EMAITZAK}

\subsection{Artikuluen bilaketa eta aukeraketa}

Pubmed-en, termino askeak eta MeSH terminoak konbinatuz 740 artikulu lortu genituen. Iragazkiak aplikatu ostean, 169 artikulu bildu genituen (ikus 1. irudia).

Askmedline-n, iragazkia aplikatu ostean 96 artikulu lortu genituen eta Tripdatabase-ren kasuan zuzenean 21 artikulu, iragazkirik aplikatu gabe (ikus 2. irudia).

Clinial Trials-en, iragazkiak aplikatu ostean 4 artikulu lortu genituen (ikus 2. irudia).

Cochrane-n kasuan, iragazkiak jarri ostean 238 artikulu eskuratu genituen (ikus 2. irudia). 
Beraz, bost datu-baseak batuta, guztira 528 artikulu eskuratu genituen. 528 artikuluetatik artikulu batzuk baztertu genituen, aukeratzeko irizpideak betetzen ez zituztelako. Artikuluak kanpoan uzteko arrazoiak 3. irudian azaltzen dira.

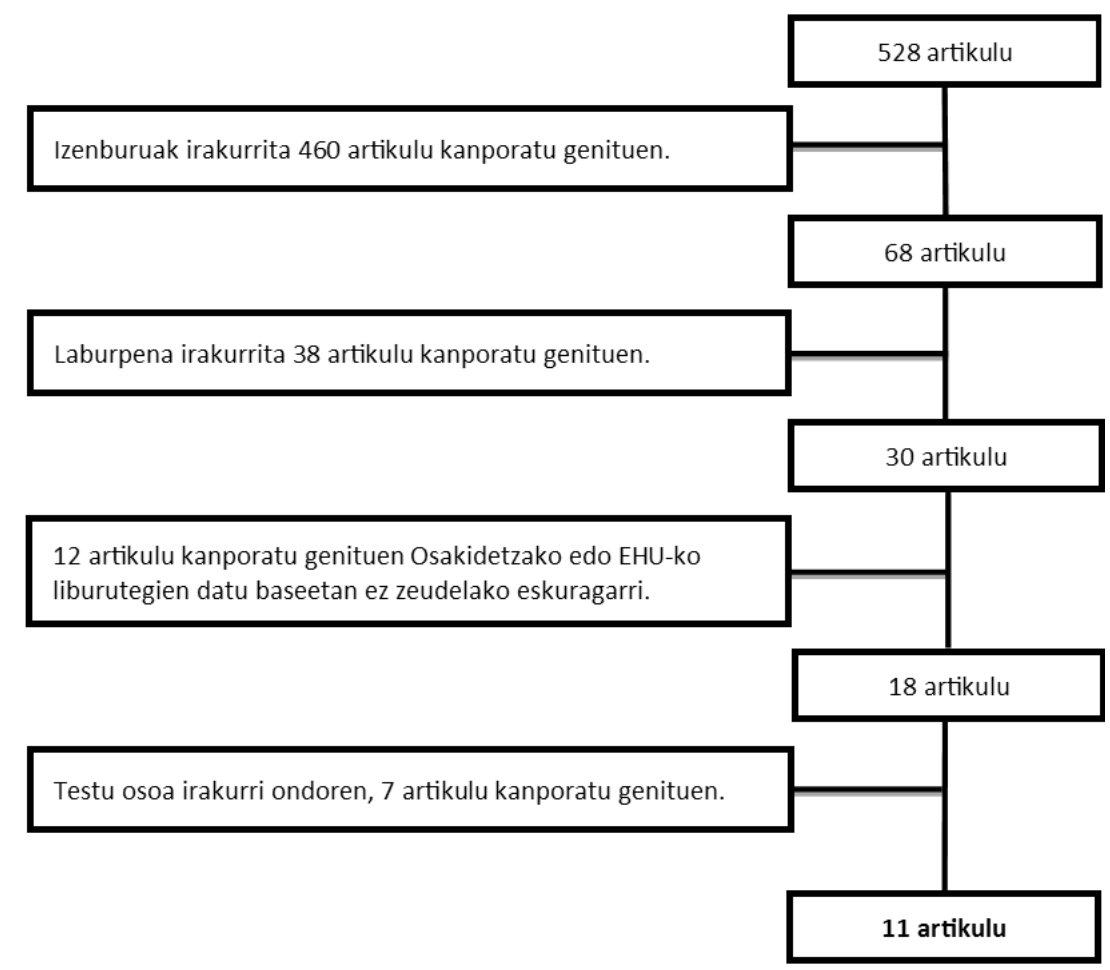

3. irudia. Artikuluak baztertzeko prozeduraren laburpen algoritmoa.

\subsection{Artikuluen kalitatearen balorazioa: JADAD eskala}

Aukeratutako 11 artikuluen kalitatearen azterketa egin genuen JADAD eskalaren bidez. Aztertutako artikulu guztiak onartuak izan ziren lortutako puntuazioa $\geq 3$ izan zelako (ikus 1. taula). 
1.taula. Artikuluen kalitatearen balorazio taula JADAD eskala erabiliz.

\begin{tabular}{rcccccc}
\hline $\begin{array}{c}\text { Zorizko } \\
\text { esleipena? }\end{array}$ & $\begin{array}{c}\text { Aleatorizazio- } \\
\text { metodoa? }\end{array}$ & $\begin{array}{c}\text { Itsu } \\
\text { bikoitzekoa? }\end{array}$ & $\begin{array}{c}\text { Itsutze- } \\
\text { metodoak? }\end{array}$ & Galerak? & Puntuazioa \\
\hline 1 & Bai & Ez & Bai & Ez & Bai & 3 \\
2 & Bai & Ez & Bai & Ez & Bai & 3 \\
3 & Bai & Ez & Bai & Ez & Bai & 3 \\
4 & Bai & Bai & Bai & Bai & Bai & 5 \\
5 & Bai & Ez & Bai & Bai & Bai & 4 \\
6 & Bai & Ez & Bai & Bai & Bai & 4 \\
7 & Bai & Bai & Bai & Bai & Bai & 5 \\
8 & Bai & Bai & Bai & Bai & Bai & 5 \\
9 & Bai & Bai & Bai & Bai & Bai & 5 \\
10 & Bai & Ez & Bai & Bai & Bai & 4 \\
11 & Bai & Bai & Bai & Bai & Bai & 5 \\
\hline
\end{tabular}

\subsection{Melatoninaren eraginkortasunaren azterketa: artikuluen emaitzak}

11 artikuluk barneratze eta kanporatze irizpideak bete zituzten eta kalitate onekoak ziren JADAD eskalaren arabera. Laginaren tamaina oso aldakorra izan zen; entsegurik txikienak 10 paziente hautatu zituen eta handienak, berriz, 791. 10 azterlanek gizonak eta emakumeak barne hartu zituzten, eta batek emakumeak soilik. 5 entseguk diseinu gurutzatua erabili zuten, hau da, talde bakoitzak lehenengo esku-hartze bat (melatonina edo plazebo) jaso zuen eta gero bestea. Aztertutako melatonina-dosiei dagokienez, txikiena 0,1 mg-koa izan zen eta handiena $6 \mathrm{mg}$-koa. Loezina arintzeko melatoninak zuen eraginkortasuna aztertzeko metodoak era askotakoak izan ziren, baina erabilienak polisomnografia, lo-egunerokoak eta lo-erregistroak izan ziren.

Aztertutako 11 entseguetatik, 2 ikerlanek ez zuten aurkitu loezinean hobekuntzarik melatonina hartu ondoren. 8 entseguk loaren kalitatearekin edo kantitatearekin lotutako parametroetan hobekuntza esanguratsuak aurkitu zituzten. Azkenik, entsegu batek melatoninak gaueko barneko melatoninaren mailarik gorena aurreratzen zuela ikusi zuen, baina loan aldaketarik eragin gabe. Aztertutako azterlanen ezaugarri guztiak 2. taulan biltzen dira. 


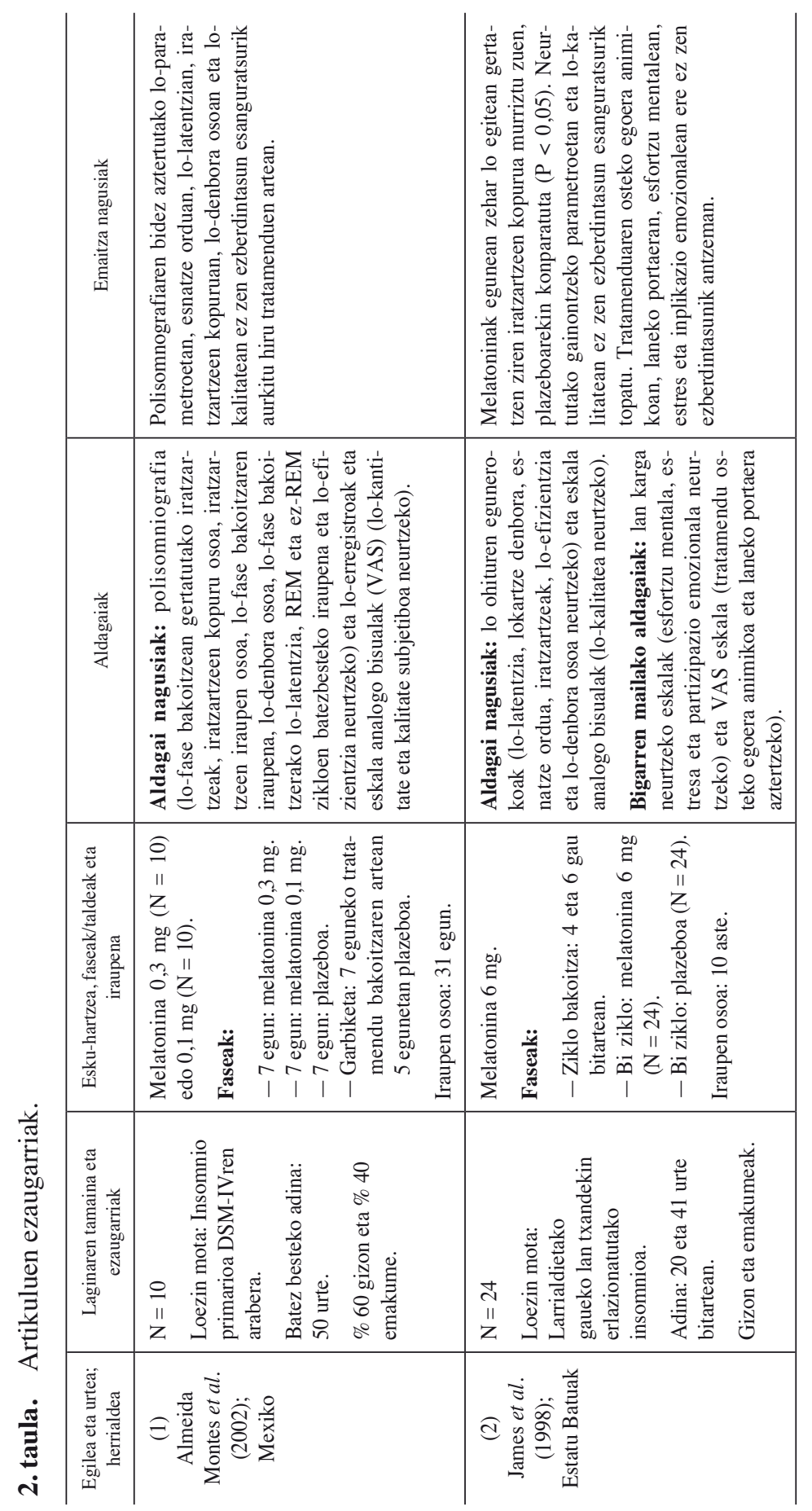

https://doi.org/10.1387/ekaia.22913 


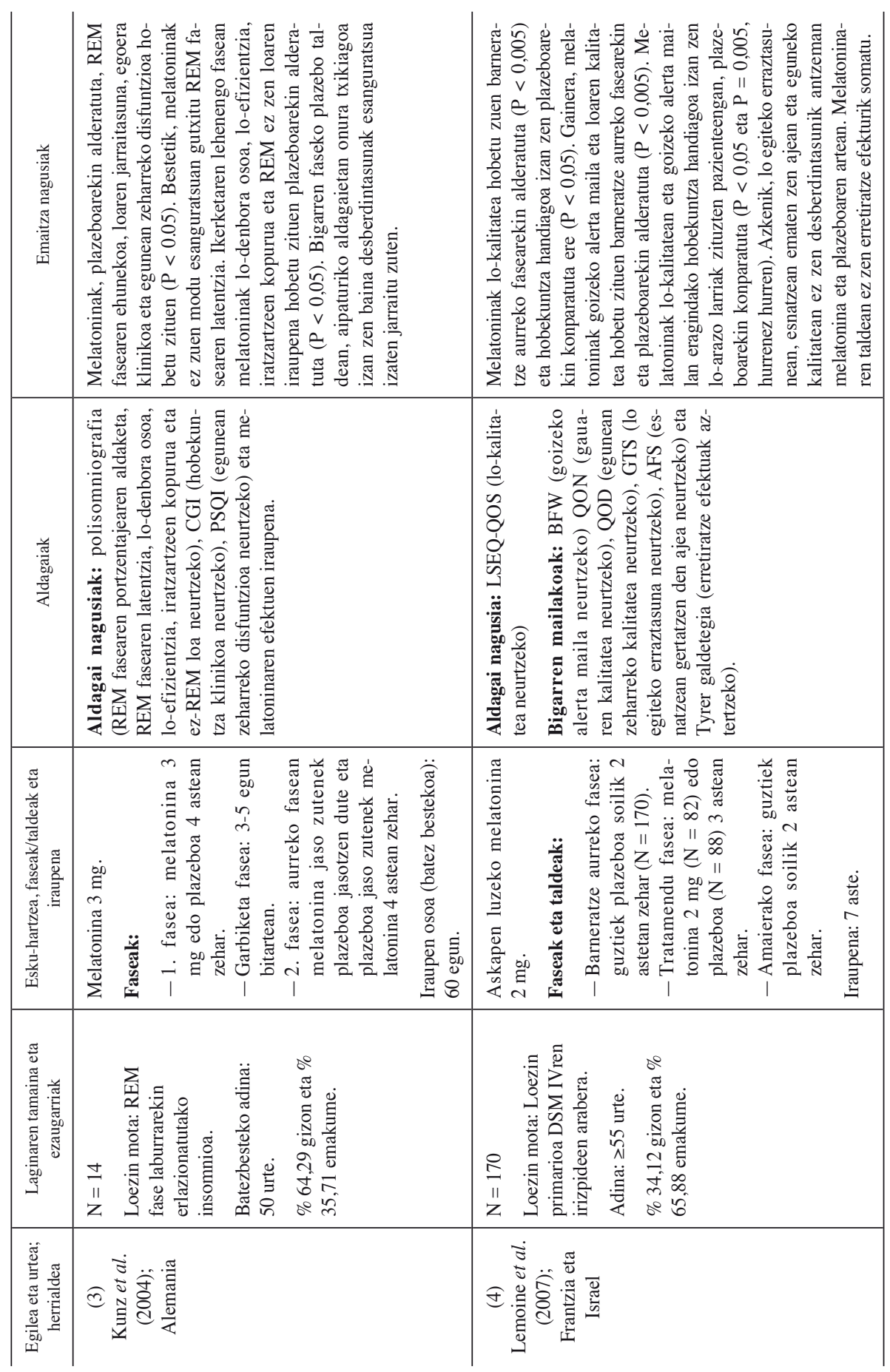




\begin{tabular}{|c|c|c|}
\hline 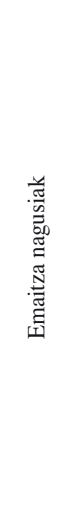 & 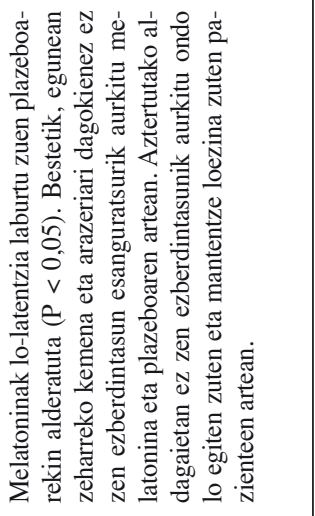 & 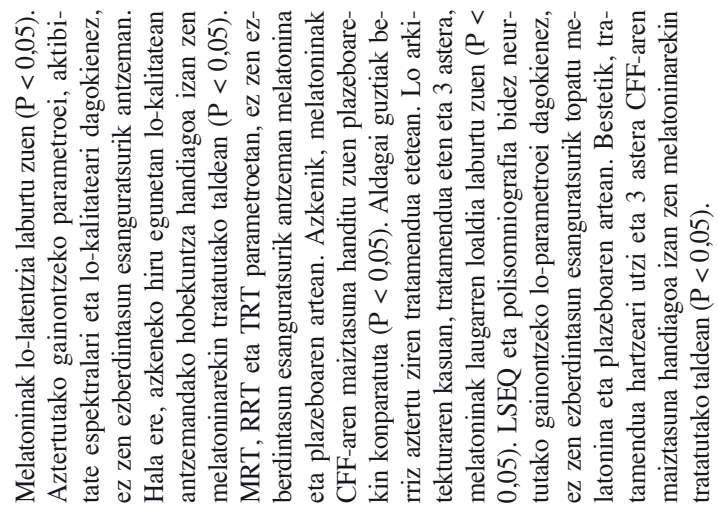 \\
\hline & 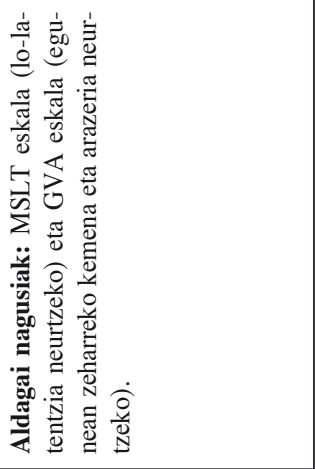 & 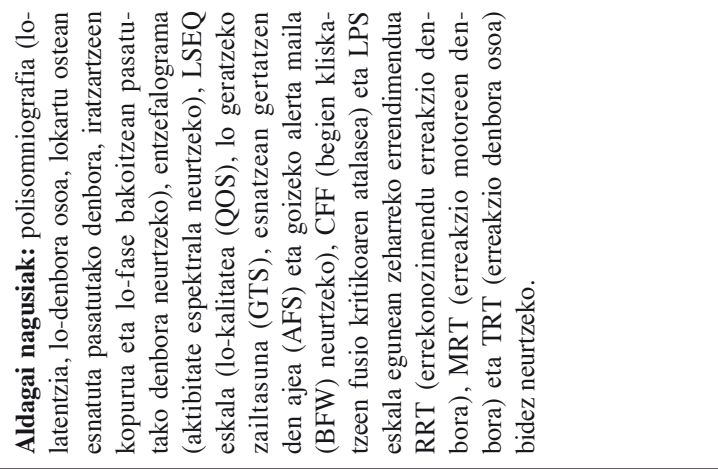 \\
\hline 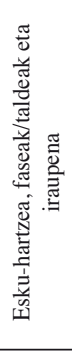 & 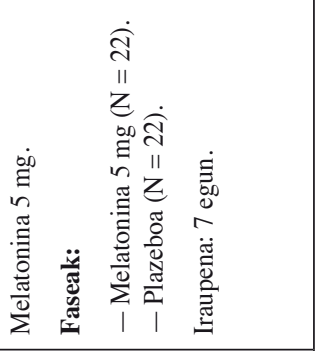 & 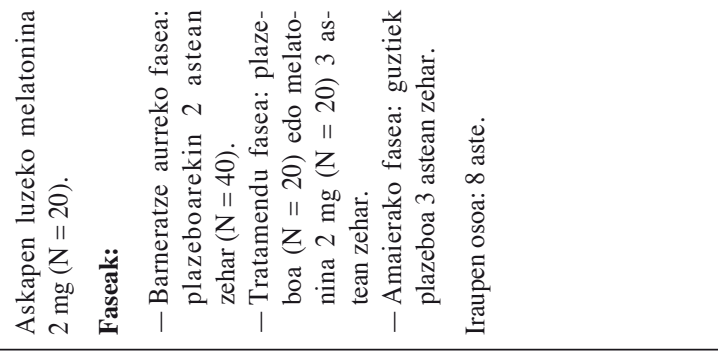 \\
\hline 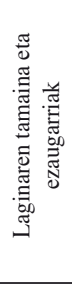 & 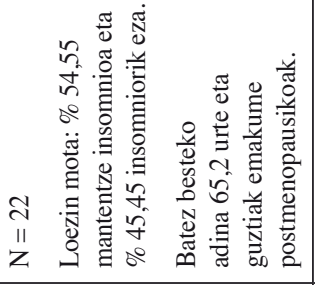 & 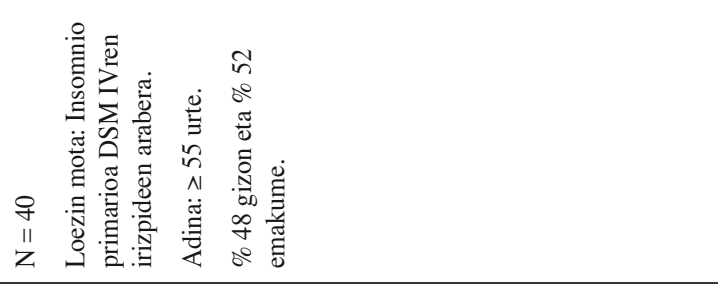 \\
\hline 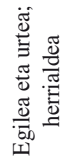 & 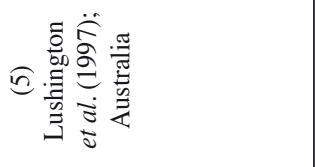 & 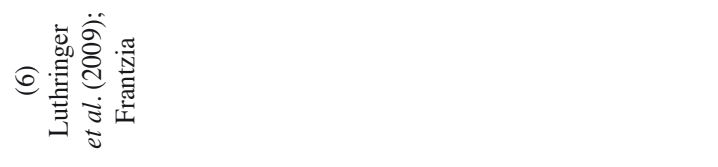 \\
\hline
\end{tabular}




\begin{tabular}{|c|c|c|}
\hline 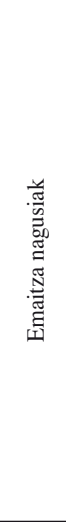 & 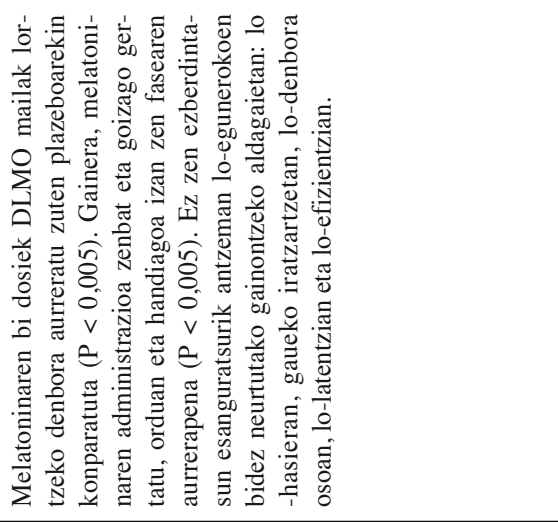 & 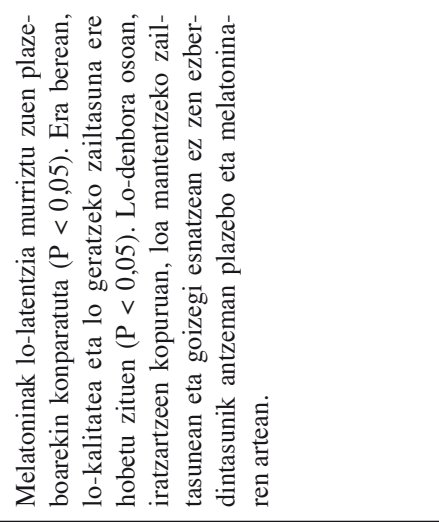 \\
\hline & 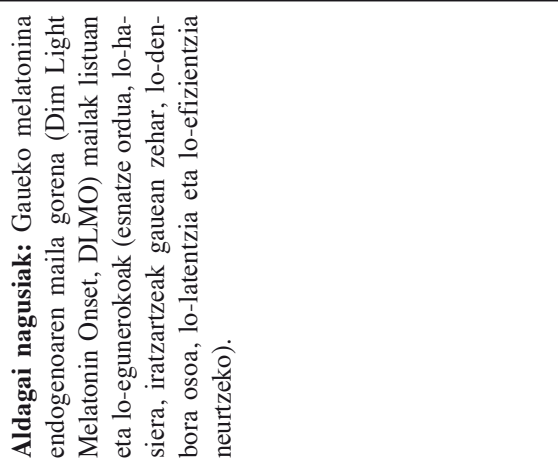 & 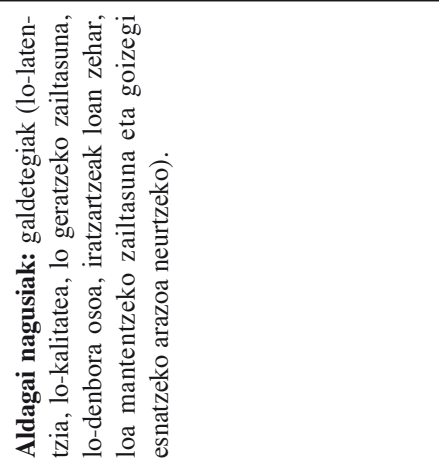 \\
\hline 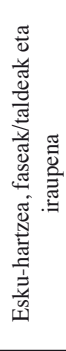 & 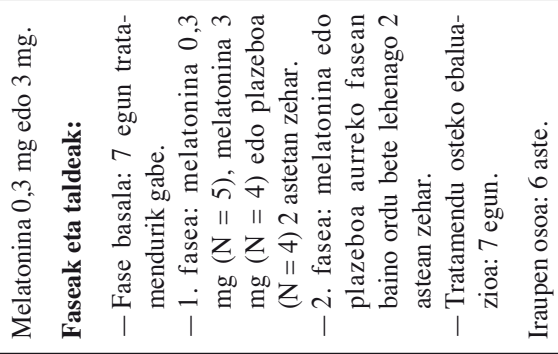 & 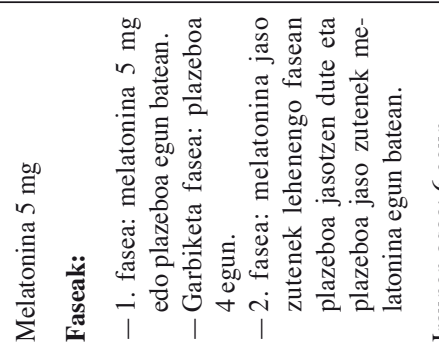 \\
\hline 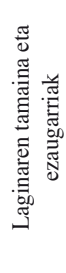 & 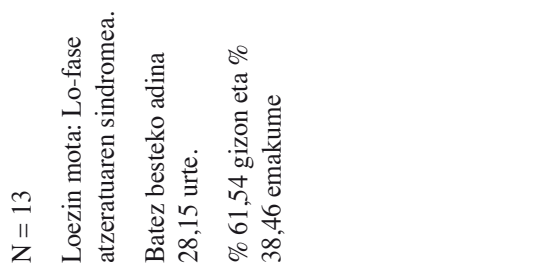 & 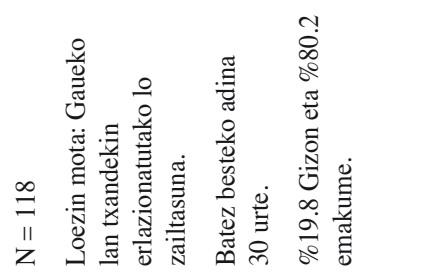 \\
\hline 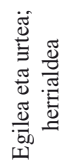 & 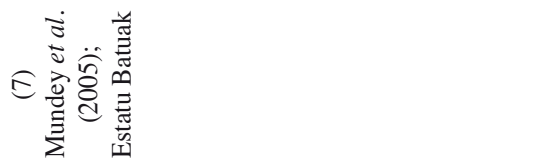 & 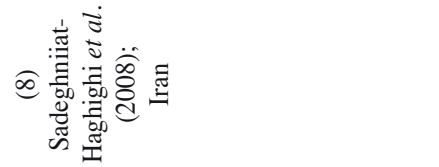 \\
\hline
\end{tabular}




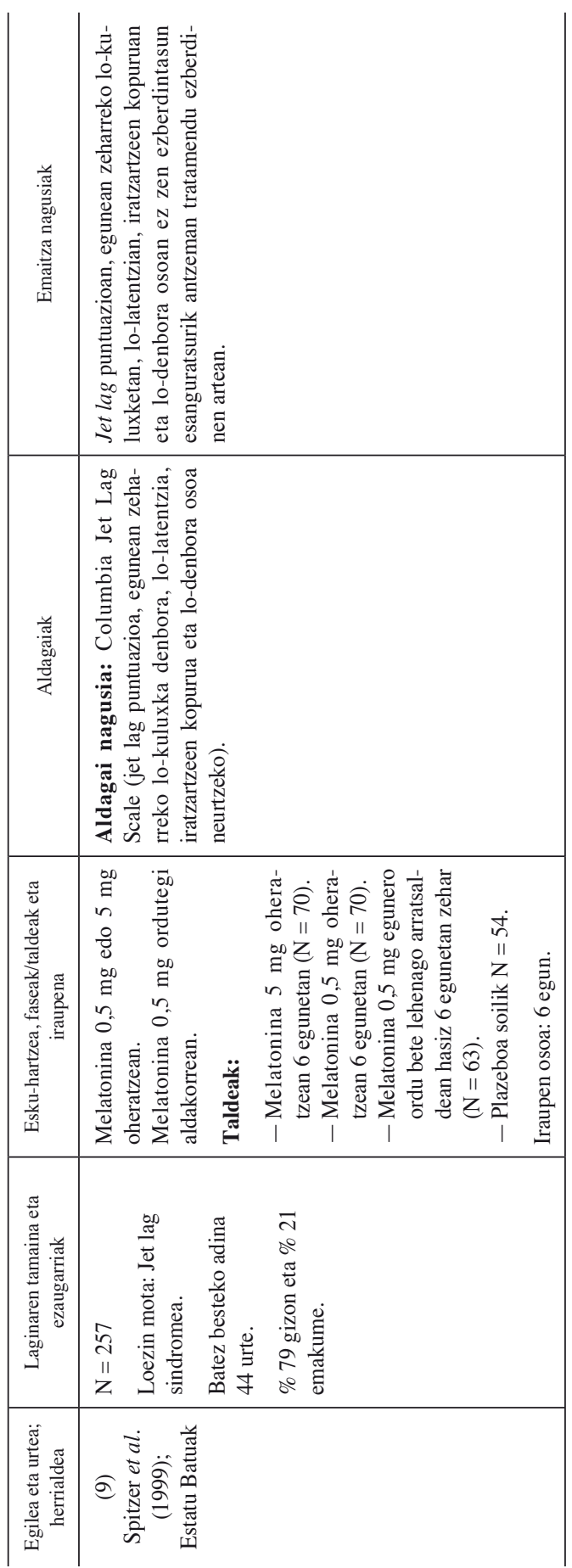

https://doi.org/10.1387/ekaia.22913 


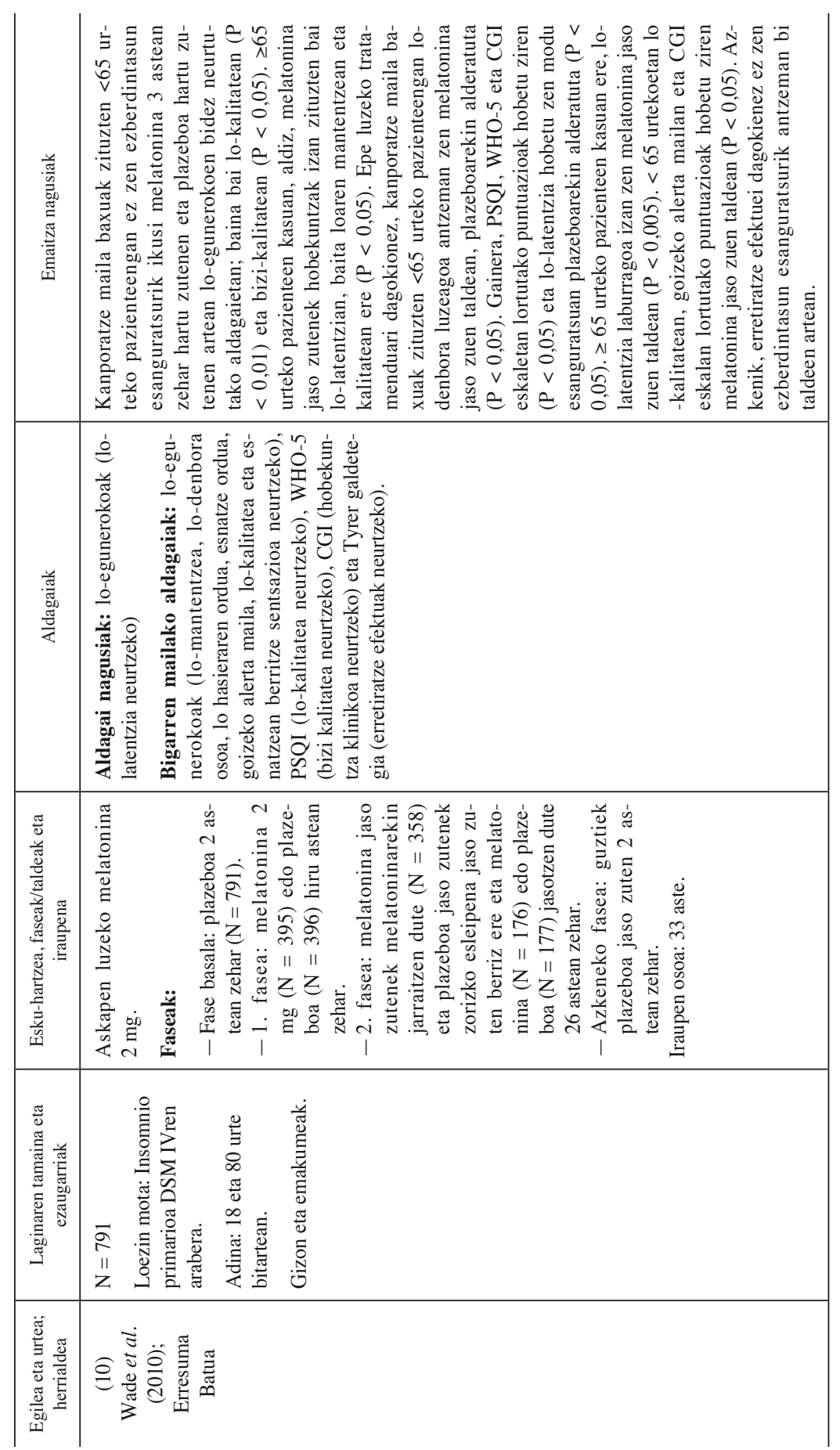




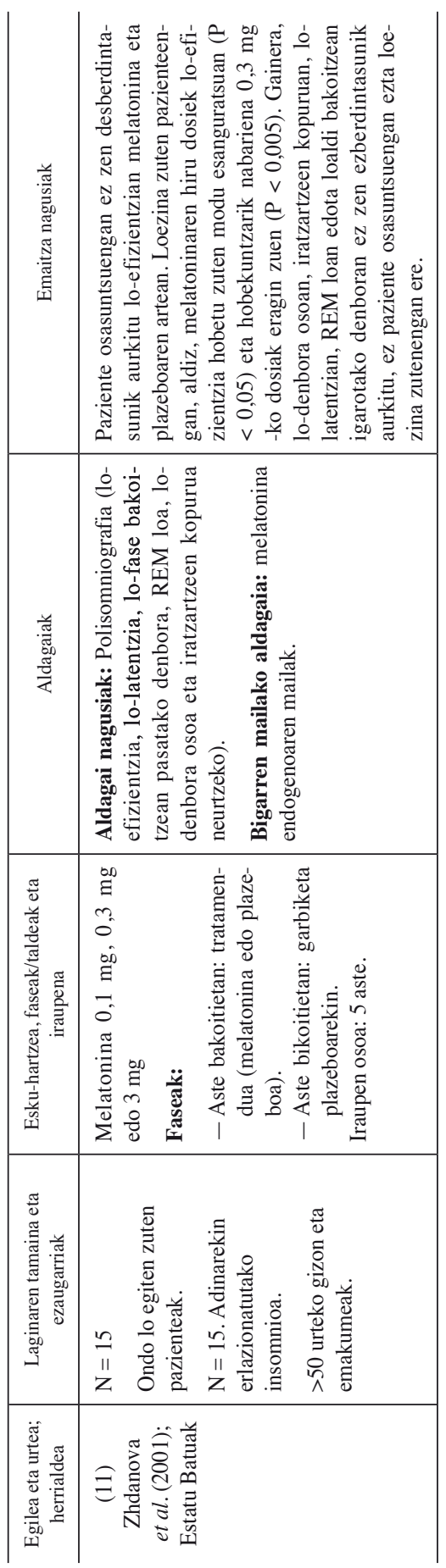

https://doi.org/10.1387/ekaia.22913 


\section{EZTABAIDA}

Entsegu klinikoetan melatoninak loezinean zuen eragina aztertzeko nazioartean balioztatutako eskala ezberdinak erabili ziren. Horien artean, LSEQ eskala erabili zen loaren kalitatea neurtzeko [21, 22] eta PSQI, loaren asaldura orokorra neurtzeko [23, 24]. Kasu batzuetan pazienteen lo-egunerokoak ere erabili ziren [24, 25]. Aldagai horietaz gain, ikerketa batzuetan aldagai objektiboagoak (polisomniografia) erabili zituzten $[22,23,26,27]$, horrela emaitzei berme handiagoa emateko.

Polisomnografia lo-parametroak objektiboki neurtzeko erreferentziazko metodoa (ingelesez «gold standard») da. Hala ere, berariazko ekipamendua behar duen teknika konplexua da eta ohiko loa oztopa dezake [28, 29]. MSLT beste metodo objektiboa da eta erreferentziazkoa da lo-latentzia neurtzeko, baina hainbat ikertzailek kritikatu dute haren baliozkotasuna [30,31]. Metodo objektiboen mugak direla eta, azterlan batzuek metodo subjektiboak erabiltzen dituzte loa baloratzeko. Metodo subjektiboen artean, lo-egunerokoak dira ikerketetan gehien erabiltzen diren baliabideak; izan ere, «lo-eguneroko adostua» garatu da modu estandarizatuan loezina baloratzeko $[32,33]$. LSEQ eta PSIQ galdetegiak ere hainbat baldintzatan balidatuta daude [11,34], baina lo-egunerokoak baino gutxiago erabiltzen dira.

Lehen mailako loezinari dagokionez, melatoninak loaren hobekuntza eragin zuela ikusi zen baliabide desberdinen bidez: LSEQ eskala, QOS (lo-kalitatea), BFW (hurrengo eguneko alerta maila) [21, 22], CFF [22], PSQI eta lo-egunerokoak [24]. Hobekuntza hori, gainera, goizeko alerta mailaren, bizi kalitatearen eta egoera emozionalaren hobetzearekin bat zetorren [24]. Almeida Montes et al.-en ikerketan, aldiz, eskalez eta lo-egunerokoez gain, polisomniografia ere erabili zuten lo-efizientzia eta lo-latentzia neurtzeko eta ez zuten ezberdintasun esanguratsurik aurkitu melatonina eta plazeboaren artean. Neurketa objektiboagoa erabiltzea alderdi positiboa da eta beste ikerketekiko desberdintasuna azal dezake. Dena dela, posible ere bada erabilitako melatoninaren dosiak emaitzen desberdintasunen oinarrian egotea. Izan ere, entsegu kliniko gehienek askapen luzeko melatoninaren $2 \mathrm{mg}$-ko dosia erabili zuten $[21,22,24]$. Almeida Montes et al.-en kasuan, aldiz, 0,3 eta $1 \mathrm{mg}-k o$ dosiak erabili ziren. Gainera, saio kliniko gehienetan 3 astean zehar luzatu zen melatoninaren tratamendua [21, 22, 24] eta Almeida Montes et al.-en kasuan, aldiz, pazienteek dosi bakoitzaren aste bakarreko tratamendua jaso zuten. Azkenik, Almeida Montes et al.-en saioan pazienteen kopurua txikia izan zen $(\mathrm{N}=10)$, beste ikerketetan paziente kopurua handiagoa izan zen bitartean.

Aipaturiko desberdintasun horietaz gain, entseguen artean pazienteen adinean ere bazeuden ezberdintasunak. Lemoine et al. eta Luthringer et al.-en kasuetan, 55 urtetik gorako pertsonak ziren eta Almeida Montes et al.-ek eta Wade et al.-ek paziente gazteagoak ere bildu zituzten. Gai- 
nera, Wade et al.-en kasuan aztertutako aldagaiak adin tarteen arabera bereizi ziren. Beraz, ebidentzien arabera, badirudi melatoninak lehen mailako loezinean duen eraginkortasunaren eta pazienteen adinaren artean erlazioa dagoela epe laburreko tratamenduan. Izan ere, 55 urtetik gorako pazienteengan melatonina eraginkorra dela frogatu da. Epe luzeko tratamenduan, aldiz, adin tarte guztietan lo-denbora osoa, lo-latentzia eta PSQIn, WHO5en eta CGIn lortutako puntuazioak hobetu ziren.

Loezin zehatzekin egindako saio klinikoei dagokienez, Zhdanova et al.-en saioan adinarekin erlazionatutako loezina zuten pazienteengan melatoninak polisomniografia bidez neurtutako lo-efizientzia hobetu zuen; baina gainerako aldagaietan ez zen ezberdintasunik aurkitu. Kasu honetan, tratamenduaren iraupena aste bakarrekoa izan zen eta gainera, paziente kopurua urria zen $(\mathrm{N}=15)$. Aipatzekoa ere bada, polisomniografia bidez egindako ikerketetan, melatoninak ez zuela lo-arkitektura aldatu [23, 26, 27]. Luthringer et al.-ek, aldiz, melatoninak laugarren loaldia laburtzen zuela ikusi zuten tratamendua eten eta 3 astera [22]. Beraz, ebidentzia gehienen arabera, neurri objetiboekin egindako ikerketetan melatoninak ez du lo-arkitektura aldatzen. Aldiz, bentzodiazepinek zein Z-hipnotikoek uhin geldoen iraupena laburtzen dute.

Mantentze loezinaren ildoan, Lushington et al.-en ikerketan, melatoninak MSLT bidez neurtutako lo-latentzian hobekuntza eragin zuen. Hala ere, gainerako aldagaiak aztertzeko erabilitako GVA eskalan ez zen eraginik ikusi. Ikerketa honetan paziente gutxi erabili ziren $(\mathrm{N}=22)$ eta guztiak emakume postmenopausikoak ziren; eta datu horiek, ikerketaren ondorioak populazioari orokortzeko muga izan daitezke.

Gaueko lan txandekin erlazionatutako loezinari dagokionez, ikerketek emaitza kontrajarriak aurkezten dituzte. James et al.-en ikerketan melatoninak lo-egunerokoetan eta VAS eskalen bidez neurtutako umore eta lan errendimenduan ez zuen eraginik erakutsi. Hala ere, aztertutako paziente kopurua urria izan zen $(\mathrm{N}=24)$. Sadeghniiat-Haghighi et al.-en ikerketan, aldiz, melatoninak galdetegi subjektiboen bidez aztertutako lo-latentzia, lokalitatea eta lo geratzeko zailtasuna hobetu zituen. Kasu honetan gainera, paziente kopurua handiagoa izan zen $(\mathrm{N}=118)$.

Loaldi atzeratuaren sindromean, melatoninak erritmo zirkadianoaren aurreratzea eragiten du eta honek, lokartzeko orduan eragina eduki dezake. Izan ere, DLMOren aurreratzea eragiten zuela ikusi zen Mundey et al.-en ikerketan. Gainera, aurreratzea melatoninaren administrazio orduarekin erlazionatuta zegoen. Hala ere, aztertutako gainerako aldagaietan melatoninak ez zuen eraginik izan. Berriki, Auld et al.-en metaanalisian, melatoninak loaldi atzeratuaren sindromea zuten pazienteen lo-latentzia murrizten zuela ikusi zen [35]. Hala ere, Mundey et al.-en kasuan bezala, ez zen eragin esanguratsurik aurkitu gainontzeko parametroetan. 
Jet lagaren kasuan, Spitzer et al.-en ikerketan ez zen ezberdintasunik antzeman melatonina eta plazeboaren artean [36]. Dena dela, badira jet lagean melatoninaren eragina baieztatu duten beste ikerketa batzuk. Adibidez, Suhner et al.-ek [37] frogatu zuten melatoninak lo-kalitatea hobetzen eta lo-latentzia laburtzen zuela. Gainera, Paul et al.-ek [38] proposatu zuten melatonina erabilgarria izan zitekeela ordu-eremu berri batera moldatzeko. Gure ikerlanaren hitz gako gisa «jet lag syndrome» erabili genuen eta hori izan daiteke aipaturiko bi artikuluak gure bilaketetan agertu ez izanaren arrazoia. Aipatzekoa da berriki Espainian melatonina duen farmako bat (Melatonite ${ }^{\circledR}$ ) baimendu dela jet laga tratatzeko.

REM fase laburrarekin erlazionatutako loezinean, melatonina Kunz et al.-en ikerketan eraginkorra izan zen, bai polisomniografia bidez neurtutako aldagai objektiboetan bai PSQI eta CGI eskalen bidez neurtutako aldagai subjektiboetan. Beraz, esan dezakegu melatoninak eragindako loaren hobekuntzak bizi-kalitatea eta eguneko disfuntzioaren hobekuntzarekin bat datozela. Ikerketaren bigarren fasean, aurreko fasean baino hobekuntza txikiagoa antzeman zen baina esanguratsua izan zen. Ondorioz, badirudi melatoninaren efektuek bere administrazio unean baino denbora luzeagoan irauten dutela.

Azkenik, aipatzekoak ere badira gure ikerlanak izan ditzakeen mugak. Alde batetik, ingelesez zeuden ikerketak bakarrik izan ditugu kontuan. Ebidentzia garrantzitsuenak ingelesez argitaratuta badaude ere, litekeena da, beste hizkuntzetan ere ebidentzia interesgarriak egotea. Bestetik, badira EHUko zein Osakidetzako liburutegietan lortu ezin izan ditugun artikuluak ere.

\section{ONDORIOAK}

Melatonina eraginkorra da 55 urtetik gorako pazienteengan lehen mailako loezina arintzeko $2 \mathrm{mg}$-ko dosian eta gutxienez 3 astean zehar administratzen denean, baina ez beste adineko pazienteengan, dosi baxuagoetan edota loezin mota zehatz batzuetarako erabiltzean. Izan ere, aipaturiko kasu horietan melatoninaren erabilera ez dago ebidentzietan oinarrituta. Interesgarria izango litzateke melatoninak izan dezakeen eraginkortasunari buruzko ikerketa gehiago egitea adin talde ezberdinetan, loezin mota ezberdinetan eta epe luzera; horrela indikazioak hobe zehazteko. Izan ere, baliteke segurtasun hobea izanik, melatonina gaur egun loezina tratatzeko gehien erabilitako farmakoen alternatiba erakargarri bihurtzea. 


\section{BIBLIOGRAFIA}

[1] American Psychiatric Assotiation. 2013. American Psychiatric Association. Diagnostic and Statistical Manual of Mental Disorders. 5. ${ }^{a}$ ed. (DSM-5). Arlington (VA), Washington, DC.

[2] Álamo González, C., Alonso Álvarez, M. L., Cañellas Dols, F., Martín Águeda, B., Pérez díaz, H., Romero Santo-Tomás, O., Terán SanTos, J. 2016. Guía Del Insomnio. Sociedad Española del Sueño.

[3] Morin, C. M., Benca, R. 2012. «Chronic insomnia». The Lancet, 379, 1129-1141.

[4] Morgenthaler, T., Kramer, M., Alessi, C., Friedman, L., Boehlecke, B., Brown, T., Coleman, J., Kapur, V., Lee-Chiong, T., Owens, J., Pancer, J., SwICK, T. 2006. «Practice parameters for the psychological and behavioral treatment of insomnia: An update. An American Academy of Sleep Medicine Report». Sleep, 29, 1415-1419.

[5] Doerr, J. P., Hirscher, V., Riemann, D., Voderholzer, U. 2010. «Disturbances of slow-wave sleep and psychiatric disorders». Nervenarzt, 81, 347-354.

[6] Álamo, C., López-Muñoz, F., Cuenca, E.Tratado SET de Trastornos Adictivos. Editorial Médica Panamericana 2006, pp. 194-211.

[7] Wilson, S., Anderson, K., Baldwin, D., Dijk, D. J., Espie, A., Espie, C., Gringras, P., Krystal, A., Nutt, D., Selsick, H., Sharpley, A. 2019. «British Association for Psychopharmacology consensus statement on evidence-based treatment of insomnia, parasomnias and circadian rhythm disorders: An update». Journal of Psychopharmacology, 33, 923-947.

[8] Rang, H. P., Dale, M. M., Ritter, J. M., Henderson, G.Rang y Dale. Farmacología. Elsevier, Madrid 2012, pp. 471-472.

[9] EkmeKcioglu, C. 2006. «Melatonin receptors in humans: Biological role and clinical relevance». Biomedicine and Pharmacotherapy, 60, 97-108.

[10] Tordjman, S., Chokron, S., Delorme, R., Charrier, A., Bellissant, E., JaAfari, N., Fougerou, C., Del Valle Bessone, C., Fajreldines, H. D., DE Barboza, G. E. D., Tolosa de Talamoni, N. G., Allemandi, D. A., CarPentieri, A. R., Quinteros, D. A., Ghareghani, M., Scavo, L., Jand, Y., Farhadi, N., Sadeghi, H., Ghanbari, A., Mondello, S., Arnoult, D., Gharaghani, S., Zibara, K., Perdana. 2019. «Protective role of melatonin on retinal ganglionar cell: In vitro an in vivo evidences». Life Sciences, 15, 1689-1699.

[11] TARRASCh, R., LAUdON, M., ZisAPEL, N. 2003. «Cross-cultural validation of the Leeds sleep evaluation questionnaire (LSEQ) in insomnia patients». Human Psychopharmacology, 18, 603-610.

[12] Buysse, D. J., Ancoli-IsRael, S., Edinger, J. D., Lichstein, K. L., Morin, C. M. 2006. «Recommendations for a standard research assessment of insomnia». Sleep, 29, 1155-1173.

[13] Carskadon, M., Rechtschaffen, A.in: Kryger, M., Roth, T., Dement, W. (Eds.), Principles and Practice of Sleep Medicine. New York 1983, pp. 665-683. 
[14] HindmarCH, I. 1994. «Instrumental assessment of psychomotor functions and the effects of psychotropic drugs». Acta Psychiatrica Scandinavica, 89, 49-52.

[15] Monk, T. H. 1989. «A visual analogue scale technique to measure global vigor and affect». Psychiatry Research, 27, 89-99.

[16] Folkard, S., Arendt, J., Clark, M. 1993. «Can melatonin improve shift workers' tolerance of the night shift? some preliminary findings». Chronobiology International, 10, 315-320.

[17] GuY, W. 1976. ECDEU Assessment Manual for Psychopharmacology. Rockville: Department of Health, Education, and Welfare.

[18] Tyrer, P., Murphy, S., Riley, P. 1990. «The benzodiazepine withdrawal symptom questionnaire». Journal of Affective Disorders, 19, 53-61.

[19] Agencia Española de Medicamentos y Productos Sanitarios.CiMA (Centro de Información online de Medicamentos de la AEMPS), https:// cima.aemps.es/cima/pdfs/ft/07392003/FT_07392003.pdf.

[20] Jadad, A. R., Moore, R. A., Carroll, D., Jenkinson, C., Reynolds, D. J. M., Gavaghan, D. J., MCQuay, H. J. 1996. «Assessing the quality of reports of randomized clinical trials: Is blinding necessary?». Controlled Clinical Trials, 17, 1-12.

[21] Lemoine, P., Nir, T., Laudon, M., Zisapel, N. 2007. «Prolonged-release melatonin improves sleep quality and morning alertness in insomnia patients aged 55 years and older and has no withdrawal effects». Journal of Sleep Research, 16, 372-380.

[22] Luthringer, R., Muzet, M., Zisapel, N., Staner, L. 2009. «The effect of prolonged-release melatonin on sleep measures and psychomotor performance in elderly patients with insomnia». International Clinical Psychopharmacology, 24, 239-249.

[23] Kunz, D., Mahlberg, R., Müller, C., Tilmann, A., Bes, F. 2004. «Melatonin in Patients with Reduced REM Sleep Duration: Two Randomized Controlled Trials». Journal of Clinical Endocrinology and Metabolism, 89, 128-134.

[24] Wade, A. G., Ford, I., Crawford, G., McConnachie, A., Nir, T., LauDON, M., ZISAPEL, N. 2010. «Nightly treatment of primary insomnia with prolonged release melatonin for 6 months: A randomized placebo controlled trial on age and endogenous melatonin as predictors of efficacy and safety». BMC Medicine, 8, 1-18.

[25] James, M., Tremea, M. O., Jones, J. S., Krohmer, J. R. 1998. «Can melatonin improve adaptation to night shift?». American Journal of Emergency Medicine, 16, 367-370.

[26] Almeida Montes, L. G., Ontiveros Uribe, M. P., Cortés Sotres, J., Heinze Martin, G. 2003. «Treatment of primary insomnia with melatonin: A double-blind, placebo-controlled, crossover study». Journal of Psychiatry and Neuroscience, 28, 191-196.

[27] Zhdanova, I. V., Wurtman, R. J., Regan, M. M., Taylor, J. A., Shi, J. P., LECLAIR, O. U. 2001. «Melatonin treatment for age-related insomnia». Journal of Clinical Endocrinology and Metabolism, 86, 4727-4730. 
[28] Dresler, M., Spoormaker, V. I., Beitinger, P., Czisch, M., Kimura, M., Steiger, A., Holsboer, F. 2014. «Neuroscience-driven discovery and development of sleep therapeutics». Pharmacology and Therapeutics, 141, 300-334.

[29] Mallinson, D. C., Kamenetsky, M. E., Hagen, E. W., Peppard, P. E. 2019. «Subjective sleep measurement: Comparing sleep diary to questionnaire». Nature and Science of Sleep, 11, 197-206.

[30] Barateau, L., Lopez, R., Franchi, J. A. M., Dauvilliers, Y. 2017. «Hypersomnolence, Hypersomnia, and Mood Disorders». Current Psychiatry Reports, 19, 1-11.

[31] Plante, D. T., Cook, J. D., Prairie, M. L. 2020. «Multimodal assessment increases objective identification of hypersomnolence in patients referred for multiple sleep latency testing». Journal of Clinical Sleep Medicine, 16, 1241-1248.

[32] Carney, C. E., Buysse, D. J., Ancoli-Israel, S., Edinger, J. D., Krystal, A. D., Lichstein, K. L., Morin, C. M. 2012. «The consensus sleep diary: Standardizing prospective sleep self-monitoring». Sleep, 35, 287-302.

[33] Maich, K. H. G., Lachowski, A. M., Carney, C. E. 2018. «Psychometric Properties of the Consensus Sleep Diary in Those With Insomnia Disorder». Behavioral Sleep Medicine, 16, 117-134.

[34] Mollayeva, T., Thurairajah, P., Burton, K., Mollayeva, S., Shapiro, C. M., Colantonio, A. 2016. «The Pittsburgh sleep quality index as a screening tool for sleep dysfunction in clinical and non-clinical samples: A systematic review and meta-analysis». Sleep Medicine Reviews, 25, 52-73.

[35] Auld, F., Maschauer, E. L., Morrison, I., Skene, D. J., Riha, R. L. 2017. «Evidence for the efficacy of melatonin in the treatment of primary adult sleep disorders». Sleep Medicine Reviews, 34, 10-22.

[36] Spitzer, R. L., Terman, M., Williams, J. B. W., Terman, J. S., Malt, U. F., Singer, F., LewY, A. J. 1999. «Jet lag: Clinical features, validation of a new syndrome-specific scale, and lack of response to melatonin in a randomized, double-blind trial». American Journal of Psychiatry, 156, 1392-1396.

[37] Suhner, A., Schlagenhauf, P., Johnson, R., Tschopp, A., Steffen, R. 1998. «Comparative study to determine the optimal melatonin dosage form for the alleviation of jet lag». Chronobiology International, 15, 655-666.

[38] Paul, M. A., Miller, J. C., Gray, G. W., Love, R. J., Lieberman, H. R., ARENDT, J. 2010. «Melatonin treatment for eastward and westward travel preparation». Psychopharmacology, 208, 377-386. 